P-ISSN:

\title{
ANALISIS IMPLEMENTASI SIMDA KEUANGAN DENGAN MENGGUNAKAN COBIT UNTUK MELIHAT EFEKTIVITAS PENGGUNAAN TEKNOLOGI INFORMASI DI PEMERINTAH KABUPATEN BLITAR
}

Novi Ira Saputri, Iwan Setya Putra

STIE Kesuma Negara Blitar

Alamat surel : iwan@stieken.ac.id

DOI: doi.org// $\mathrm{xxxxx}$

Informasi Artikel

Tanggal Masuk November $26^{\text {th }}, 2020$

Tanggal Revisi

Tanggal diterima

ember $2^{\text {nd }}, 2020$

December $19^{\text {th }}, 2020$

Keywods:

SIMDA Finance, Effectiveness of the Use of Information Technology, COBIT.

Abstract:

The changing employee position and the changing SIMDA Financial application to adjust the new policy of applying from cash basis to accrual basis in Blitar District Government requires employees to continue learning to achieve the goal of applying information technology in the form of SIMDA Finance application effectively. The purpose of this study was to analyze the implementation of SIMDA Finance by using COBIT to see the effectiveness of the use of information technology in Blitar District Government. The analysis technique uses a maturity level. By using the COBIT method to analyze the result, the PO domain size (Planning and Organization) produces level 3.54 - 4.36 and the DS domain (Conducting and Support) produces level $3.72-4.28$, meaning that the organization has reached level 4.

Kata Kunci:

SIMDA

Keuangan, Efektivitas Penggunaan Tekonologi Informasi, COBIT.

\section{Abstrak:}

Posisi pegawai yang sering berganti dan aplikasi SIMDA Keuangan yang mengalami perubahan untuk menyesuaikan penerapan kebijakan baru dari cash basis ke accrual basis di Pemerintah Kabupaten Blitar mengharuskan pegawai untuk terus melakukan pembelajaran untuk mencapai tujuan penerapan teknologi informasi berupa aplikasi SIMDA Keuangan secara efektif. Tujuan penelitian ini untuk menganalisis implementasi SIMDA Keuangan dengan menggunakan COBIT untuk melihat efektivitas penggunaan teknologi informasi di Pemerintah Kabupaten Blitar. Teknik analisis menggunakan maturity level atau tingkat kematangan. Dengan menggunakan metode COBIT untuk menganalisis hasilnya adalah ukuran domain PO (Perencanaan dan Organisasi) menghasilkan level 3,54 - 4,36 dan domain DS (Penghantar dan Dukungan) menghasilkan level 3,72 4,28 artinya organisasi telah mencapai level 4 . 


\section{PENDAHULUAN}

Penerapan aplikasi SIMDA Keuangan di Kabupaten Blitar sejak tahun 2008 dan mengalami beberapa kali pengembangan sistem. Sistem dikembangkan seiring dengan kebijakan baru dari pemerintah yang diatur dalam PP No.71 Tahun 2010 berisi Penerapan Standar Akuntansi Pemerintahan Accrual Basis Pada PEMDA, tentunya hal tersebut mengharuskan pengembangan baru dari BPKP dan penggunanya untuk menyesuaikan sistem yang baru dan penerapan sepenuhnya selambat-lambatnya tahun 2015. Pemerintah daerah berkewajiban membuat APBD untuk dipertanggungjawabkan kepada pemerintah pusat berupa Laporan Keuangan PEMDA berisi LRA, laporan arus kas, neraca, dan CALK, sehingga dalam pelaporannya harus relevan, andal, dapat dibandingkan, dan mudah dipahami. Untuk menyajikan laporan keuangan, pemerintah diwajibkan menghasilkan laporan keuangan berkualitas, SDM yang ahli di bidang akuntansi dan paham terhadap peraturan-peraturan akuntansi pemerintahan. Selain itu, dalam menyajikan laporan keuangan berkualitas juga diperlukan teknologi informasi yang tersistematis.

Aplikasi SIMDA Keuangan yang diterapkan di Pemerintah Kabupaten Blitar saat ini adalah versi 2.7.12, untuk mengelola keuangan daerah dari penganggaran, penatusahaan, akuntansi sampai pelaporan serta sudah terintegrasi secara online dengan setiap SKPD. Namun dalam penerapan aplikasi SIMDA Keuangan ditemukan beberapa kendala baik dari sistem maupun sumber daya manusia. Sistem SIMDA Keuangan beberapa kali mengalami perubahan salah satunya untuk menyesuaikan kebijakan baru dari pemerintah yang diatur dalam PP No.71 Tahun 2010 berisi Penerapan Standar Akuntansi Pemerintahan Accrual Basis Pada PEMDA, tentunya hal tersebut mengharuskan penggunanya untuk menyesuaikan sistem yang baru dari cash basis ke accrual basis dan penerapan sepenuhnya selambat-lambatnya tahun 2015. Hal inilah yang membuat para SKPD enggan untuk terus belajar dan memahami sistem yang baru.

Faktor lain yang menghambat penerapan SIMDA Keuangan adalah sumber daya manusia, yaitu SKPD sebagai penggunanya yang sering berganti posisi karena kenaikan jabatan atau faktor lain. Menurut hasil wawancara penulis dengan Kepala BPKAD Kabupaten Blitar mencatat bahwa bagian bendahara yang intensitasnya sering berganti hal ini juga menghambat proses penginputan data dan pembuatan Laporan Keuangan Pemerintah Daerah (LKPD), karena penginputan data dalam waktu yang singkat dan perlunya pembelajaran dari pengguna dalam menginput data sehingga validitas data masih diragukan. Hal lain yang menghambat adalah antara orang lama dengan orang baru memiliki pemahaman yang berbeda saat menggunakan SIMDA Keuangan sehingga kecepatan pemahaman penggunaan SIMDA Keuangan ini juga tidak lebih baik. Hambatan-hambatan inilah yang akan mengurangi proses tercapainya keefektifan diterapkannya aplikasi SIMDA Keuangan. Untuk memastikan keefektifan penerapan aplikasi SIMDA Keuangan tercapai maka diperlukan rancangan perbaikan sehingga tujuan penerapan SIMDA Keuangan dapat tercapai. Model COBIT dapat mengukur kehandalan penggunaan sistem aplikasi, bagi manajemen atau Pemerintah dapat memberikan manfaat untuk menentukan keputusan dan menyusun strategi.

Hasil penelitian Noor Azizah (2017), melakukan penelitian yang berjudul "Audit Sistem Informasi Menggunakan Framework Cobit 4.1 Pada E-Learning Unisnu Jepara" dengan variabel audit sistem informasi dan e-laearning. Kesimpulan yang didapatkan yaitu tingkat kematangan (maturity level) pada implementasi e-learning UNISNU Jepara khusus pada domain DS berada pada level 4 yang berarti sudah terukur dan terintegrasi 
antar proses yang berlangsung analisa GAP dengan kondisi yang diharapkan dengan kondisi saat ini.

Hasil penelitian Dedy Hermanto dan Desy Iba Ricoida (2014) melakukan penelitian yang berjudul "Analisis Pengukuran Tingkat Kematangan Menggunakan Kerangka COBIT 4.1 (Studi Kasus PT.SMI)" dengan variabel tata kelola TI dan tingkat kematangan. Kesimpulan penelitian tersebut yaitu tingkat kematangan TI pada level 3 "defined" artinya tingkat kematangan belum sesuai dengan harapan perusahaan, terdapat GAP tingkat kematangan saat ini dan yang diharapkan, serta belum maksimalnya aturan dan dokumentasi yang terkait TI.

Hasil penelitian Iwan Setya Putra (2011) melakukan penelitian yang berjudul "Evaluasi Penerapan Sistem Informasi Akuntansi Pada Sistem Dan Prosedur Belanja Di Pemerintah Kota Blitar" dengan variabel efektivitas, efisiensi, dan sistem informasi penyusunan APBD. Kesimpulan dari penelitian tersebut yaitu kualitas efektivitas sistem, kualitas efisiensi sistem dan penerapan SIP APBD di Pemerintah Kota Blitar telah mencapai level kematangan level 4 (managed and measurable).

Hasil penelitian Iwan Setya Putra (2011), melakukan penelitian yang berjudul "Efektivitas Pengelolaan Sistem Informasi Akuntansi Dalam Pengendalian Persediaan Obat Pada Rumah Sakit Syuhada Haji Blitar" dengan variabel sistem informasi akuntansi, sistem pengendalian persediaan dan efektivitas sistem informasi. Kesimpulan dari penelitian tersebut yaitu sistem informasi akuntansi cukup berperan dalam menunjang efektivitas dalam sistem pengendalian persediaan obat di Rumah Sakit Syuhada Haji Blitar.

Tujuan dari penelitian ini yaitu untuk menganalisis implementasi SIMDA Keuangan dengan menggunakan COBIT untuk melihat efektivitas penggunaan teknologi informasi di Pemerintah Kabupaten Blitar.

\section{TELAAH LITERATUR}

Sistem Informasi Manajemen

1. Definisi sistem

Menurut Sutabri (2014:7) sistem adalah kumpulan unsur yang saling berhubungan dan saling bekerja sama dalam mencapai tujuan, sedangkan menurut O’Brien dan Marakas (2014:4) sistem yaitu seluruh komponen yang berkaitan dan mempunyai batasan yang jelas untuk pencapaian tujuan bersama. Jadi, sistem merupakan kumpulan seluruh unsur-unsur untuk mencapai tujuan yang sama dan unsur-unsur tersebut saling berkaitan.

2. Definisi informasi

Informasi yaitu hasil pengolahan data yang digunakan untuk pengambilan keputusan (Sutabri, 2014:25). Informasi memberikan makna dari hasil pengolahan data dan bermanfaat untuk memberikan gambaran keputusan (Darmawan dan Fauzi, 2013:2). Jadi, informasi merupakan hasil dari runtutan proses olah data yang berguna untuk pengambilan keputusan.

3. Definisi sistem informasi

Sistem yang digunakan organisasi untuk mengolah transaksi sehari-sehari dan penunjang operasional organisasi yang didalamnya berisi strategi organisasi yang bersifat manajerial sehingga menghasilkan laporan-laporan untuk para pemangku kepentingan disebut dengan sistem informasi (Sutabri, 2014:40).

Menurut pendapat Sudiro, Rahadian, dan Prima (2017:5), sistem informasi merupakan sistem yang terkonsep, digunakan manajer untuk mengawasi dan 
mengendalikan sistem yang dijalankan organisasi, serta untuk mengubah input hingga menjadi ouput.

Jadi, sistem informasi merupakan sistem yang berisi strategi yang dikendalikan oleh manajer, sebagai pengendalian dan pengawasan suatu sistem serta untuk menghasilkan laporan sebagai bentuk pertanggungjawaban pada perusahaan.

4. Definisi sistem informasi manajemen

Sudiro, Rahadian, dan Prima (2017:6), berpendapat bahwa sistem yang digunakan oleh manajer guna mengolah data, sehingga transaksi yang diolah menjadi informasi yang bermanfaat disebut dengan sistem informasi manajemen. Selain itu, sistem informasi manajemen digunakan untuk membantu operasional suatu organisasi, dan menghasilkan informasi untuk membantu manajer dalam pengambilan keputusan (Sutabri, 2014:83).

Jadi, sistem informasi manajemen adalah perpaduan antara pengolah sistem yaitu manusia dengan teknologi informasi sehingga akan menghasilkan informasi yang relevan, akurat, dan lengkap untuk dijadikan dasar pengambilan keputusan oleh manajemen.

\section{Sistem Informasi Manajemen Daerah (SIMDA)}

SIMDA adalah wujud dari implementasi e-government yang diinstruksikan oleh Presiden kemudian dalam implentasinya diselaraskan dengan PERMENDAGRI NOMOR 13 TAHUN 2006 yang berisi Pedoman Pengelolaan Keuangan Daerah. SIMDA dikembangkan untuk mempermudah satuan kerja perangkat daerah dalam mengelola keuangan agar lebih efektif, efisien, dan ekonomis (BPKP, 2008:14).

Suatu organisasi memerlukan teknologi yang digunakan untuk mengolah informasi secara efektif, menunjang keberlangsungan suatu usaha dan unggul dari pada pesaing, tidak terkecuali pada sektor pemerintahan. Pemerintah telah memberikan fasilitas dengan memanfaatan teknologi dan informasi berupa aplikasi SIMDA yang berbasis informasi keuangan dan digunakan untuk menyusun LKPD. Di dalam penerapannya, aplikasi SIMDA berfungsi sebagai penatausahaan keuangan daerah. Oleh karena itu, diperlukan pengguna yang ahli dalam bidangnya yang mampu mengelola database, software, dan hardware seperti bagian penganggaran, pengelola keuangan, bendahara, pengelola teknis kegiatan dan pengguna akhir aplikasi SIMDA (BPKP, 2008:87).

\section{SIMDA Keuangan}

Wujud program yang digunakan pemerintah untuk mengelola keuangan daerah secara terintegrasi dapat digunakan untuk menyusun anggaran, penatausahaan, akuntansi, dan pelaporan yang diterapkan dalam bentuk aplikasi disebut dengan SIMDA Keuangan (BPKP, 2008:14).

Badan penyelenggara keuangan daerah memberikan instruksi agar kualitas sistem penyelenggaaraan keuangan daerah ditingkatkan agar otonomi daerah berjalan dengan sukses. Dengan adanya instruksi tersebut, maka BPKP mengembangkan teknologi informasi untuk meringankan pekerjaan pemerintah untuk menyajikan informasi keuangan yang cepat, lengkap, dapat diuji kebenarannya, akurat, dan relevan. Software ini disebut dengan SIMDA Keuangan (BPKP, 2008:14).

BPKP (2008:15), aplikasi SIMDA Keuangan memberikan output sebagai berikut:

1. Penganggaran meliputi:
a. Rencana Kerja Anggaran (RKA)
b. Dokumen Pelaksanaan Anggaran (DPA)
c. Surat Penyediaan Dana (SPD)

2. Penatausahaan meliputi:
a. Surat Permintaan Pembayaran (SPP) 

b. Surat Perintah Membayar (SPM)
c. Surat Perintah Pencairan Dana (SP2D)
d. Surat Tanda Setoran (STS)
e. Registrasi
f. Surat pengendalian lainnya

3. Akuntansi dan pelaporan meliputi:
a. Jurnal
b. Buku besar
c. Buku pembantu
d. Laporan realisasi anggaran
e. Laporan arus kas
f. Neraca

Menurut (BPKP, 2008:15) penjelasan mengenai penggunaan SIMDA Keuangan dijabarkan dalam pedoman penggunaan sistem dan prosedur yang terdiri dari penyusunan anggaran, penatausahaan, akuntansi dan pelaporan, serta cara mengoperasikan aplikasi SIMDA Keuangan.

Kegunaan aplikasi SIMDA Keuangan antara lain sebagai berikut:
a. Mempermudah pemerintah untuk mengelola keuangan daerah.
b. Penyusunan laporan keuangan yang dihasilkan lebih akurat dan efisien.
c. Penyimpanan data keuangan yang berupa database.
d. Informasi yang dihasilkan akurat, lebih efisien waktu dan efektif dalam menghasilkan laporan yang berguna untuk stakeholder.
e. Dalam melakukan proses audit oleh auditor dipermudah, karena menggunakan electronic data processing audit.

\section{COBIT}

Menurut Surbakti (2012:2) COBIT adalah sekumpulan dokumentasi best practices untuk IT Governance yang dapat membantu auditor, pengguna (user), dan manajemen, untuk menjembatani antara risiko bisnis, kebutuhan control dan masalah-masalah teknis TI. Berikut kriteria kinerja COBIT:

1. Efektivitas artinya guna memperoleh informasi yang relevan dan berhubungan dengan proses bisnis seperti penyampaian informasi dengan benar, konsisten, dapat dipercaya dan tepat waktu.

2. Efisiensi artinya memfokuskan pada ketentuan informasi melalui penggunaan sumber daya yang optimal.

3. Kerahasiaan artinya memfokuskan proteksi terhadap informasi yang penting dari orang yang tidak memiliki hak otorisasi.

4. Ketersediaan artinya berhubungan dengan informasi yang tersedia ketika diperlukan dalam proses bisnis sekarang dan yang akan datang.

5. Kepatuhan artinya sesuai menurut hukum, peraturan dan rencana perjanjian untuk proses bisnis.

6. Keakuratan informasi artinya berhubungan dengan ketentuan kecocokan informasi untuk manajemen mengoperasikan entitas dan mengatur pelatihan keuangan dan kelengkapan laporan pertanggungjawaban.

Menurut Putra (2011:87), COBIT mencakup tujuan pengendalian yang terdiri dari 4 domain yaitu:

a. Perencanaan dan Organisasi

Domain ini mencakup pembahasan tentang identifikasi dan strategi investasi teknologi informasi yang dapat memberikan yang terbaik untuk mendukung pencapaian tujuan bisnis. Selanjutnya pengelolaan organisasi dan infrastruktur 
teknologi informasi perlu dipertimbangkan untuk mencapai hasil yang optimal dan yang paling menguntungkan.

b. Perolehan dan Implementasi

Domain ini mencakup mengidentifikasi teknologi informasi persyaratan, memperoleh teknologi, dan menerapkannya dalam proses bisnis perusahaan. Domain ini juga mengidentifikasi perkembangan rencana pemeliharaan yaitu perusahaan harus mengadopsi untuk memperpanjang kehidupan sebuah sistem teknologi informasi dan komponennya.

c. Penyerahan dan Pendukung

Domain ini lebih memusatkan pada ukuran aspek dukungan teknologi informasi terhadap kegiatan operasional bisnis berupa tingkat jasa layanan teknologi informasi dan aspek urutan yang meliputi masalah keamanan dan pelatihan.

d. Monitoring

Semua proses teknologi informasi yang perlu dinilai secara berkala agar kualitas dan tujuan dukungan teknologi informasi tercapai

COBIT mempunyai model kematangan (maturity models) untuk mengontrol prosesproses TI dengan menggunakan metode penilaian (scoring) sehingga suatu organisasi dapat menilai proses-proses TI yang dimilikinya dari skala non-existent sampai dengan optimized (dari 0 sampai 5) berikut penjelasannya:

1. Level 0-0,50 (non existent) artinya tidak adanya prosedur sistem informasi dalam sebuah organisasi. Sehingga tidak teridentifikasi.

2. Level 0,51-1,50 (initial) artinya tidak adanya prosedur sistem informasi dalam sebuah organisasi, individu mulai tersadar akan pentingnya prosedur sistem informasi.

3. Level 1,51-2,50 (repeatable) artinya organisasi mulai menerapakan prosedur sistem informasi namun hanya sebatas diterapkan tidak ada komunikasi formal tentang prosedur standar tersebut.

4. Level 2,51-3,50 (defined process) artinya organisasi sudah menerapakan prosedur sistem informasi yang berstandar, terdokumentasi, dan dikomunikasikan namun penggunaannya tergantung masing-masing individu mau mengikuti atau tidak.

5. Level 3,51-4,50 (managed) artinya organisasi dapat mengukur dan memonitor prosedur yang ada sehingga mudah ditanggulangi jika terjadi penyimpangan. Proses yang ada sudah berjalan dengan baik dan konstan.

6. Level 4,51-5,0 (optimized) artinya proses yang ada sudah mencapai best practice melalui proses perbaikan yang terus menerus. Teknologi informasi sudah digunakan terintegrasi untuk otomatisasi proses kerja dalam organisasi, meningkatkan kualitas, efektifitas serta kemampuan beradaptasi terhadap organisasi.

\section{METODE PENELITIAN}

Populasi menggunakan semua pegawai BPKAD Kabupaten Blitar. Sampel menggunakan sampel jenuh yaitu sampel yang diambil dari seluruh populasi yang ada, hal ini dilakukan karena populasi yang relatif kecil. Sampel tersebut yaitu seluruh pegawai BPKAD Kabupaten Blitar 50 orang. Jenis penelitian yang dilakukan menggunakan deskriptif kuantitatif, artinya penjelasan berupa angka mengenai hasil dari perhitungan kuesioner. Teknik pengumpulan data menggunakan wawancara dan kuesioner. Teknik analisa data dengan cara: 1) Kuesioner yang telah dibuat berdasarkan domain pada COBIT dianalisa menggunakan maturity level guna mengetahui seberapa tingkat kematangan suatu organisasi dalam menerapkan 
teknologi informasi, 2) Hasil dari maturity level dievaluasi bagaimana keadaan organisasi menerapkan teknologi informasi, 3) Menjelaskan bagaimana implementasi informasi dan memberikan solusi terkait permasalahan yang ada.

\section{HASIL DAN PEMBAHASAN}

Untuk mengetahui efektivitas penggunaan teknologi informasi di Pemerintah Kabupaten Blitar, berikut rumus untuk menghitung maturity level:

$$
\text { Maturity level }=\frac{\sum \text { (Total Jawaban x Bobot) }}{\text { Jumlah Responden }}
$$

Berikut hasil dari rekapitulasi kuesioner dengan domain PO (Perencaan dan Organisasi):

Tabel 1 Hasil Rekapitulasi Domain PO

\begin{tabular}{|c|c|c|c|c|c|c|c|c|c|}
\hline \multirow[b]{2}{*}{ Responden } & \multicolumn{7}{|c|}{ Pertanyaan } & \multicolumn{2}{|c|}{ Maturity Level } \\
\hline & 1 & 2 & 3 & 4 & 5 & 6 & 7 & $\Sigma$ & Mean \\
\hline 1 & 5 & 5 & 4 & 5 & 4 & 4 & 4 & 31 & 4.4 \\
\hline 2 & 5 & 4 & 4 & 4 & 3 & 3 & 4 & 27 & 3.9 \\
\hline 3 & 5 & 4 & 4 & 5 & 4 & 4 & 4 & 30 & 4.3 \\
\hline 4 & 4 & 3 & 4 & 4 & 3 & 3 & 3 & 24 & 3.4 \\
\hline 5 & 5 & 4 & 3 & 5 & 4 & 4 & 4 & 29 & 4.1 \\
\hline 6 & 4 & 3 & 2 & 4 & 3 & 2 & 2 & 20 & 2.9 \\
\hline 7 & 5 & 4 & 4 & 5 & 4 & 4 & 4 & 30 & 4.3 \\
\hline 8 & 4 & 4 & 3 & 5 & 4 & 4 & 3 & 27 & 3.9 \\
\hline 9 & 4 & 4 & 3 & 5 & 4 & 4 & 5 & 29 & 4.1 \\
\hline 10 & 5 & 4 & 4 & 4 & 4 & 3 & 3 & 27 & 3.9 \\
\hline 11 & 5 & 4 & 4 & 5 & 4 & 4 & 4 & 30 & 4.3 \\
\hline 12 & 4 & 3 & 3 & 5 & 4 & 4 & 3 & 26 & 3.7 \\
\hline 13 & 5 & 4 & 4 & 5 & 4 & 3 & 4 & 29 & 4.1 \\
\hline 14 & 4 & 4 & 3 & 3 & 3 & 2 & 2 & 21 & 3.0 \\
\hline 15 & 4 & 3 & 2 & 4 & 4 & 3 & 3 & 23 & 3.3 \\
\hline 16 & 3 & 2 & 2 & 3 & 2 & 2 & 3 & 17 & 2.4 \\
\hline 17 & 5 & 3 & 3 & 5 & 4 & 4 & 4 & 28 & 4.0 \\
\hline 18 & 3 & 3 & 2 & 4 & 4 & 3 & 3 & 22 & 3.1 \\
\hline 19 & 5 & 5 & 4 & 5 & 3 & 3 & 3 & 28 & 4.0 \\
\hline 20 & 4 & 4 & 4 & 4 & 4 & 3 & 3 & 26 & 3.7 \\
\hline 21 & 3 & 3 & 2 & 4 & 3 & 3 & 2 & 20 & 2.9 \\
\hline 22 & 5 & 5 & 4 & 4 & 5 & 3 & 3 & 29 & 4.1 \\
\hline 23 & 4 & 4 & 3 & 5 & 4 & 4 & 4 & 28 & 4.0 \\
\hline 24 & 5 & 3 & 4 & 5 & 4 & 3 & 3 & 27 & 3.9 \\
\hline 25 & 2 & 1 & 2 & 2 & 1 & 1 & 2 & 11 & 1.6 \\
\hline 26 & 4 & 4 & 4 & 5 & 3 & 5 & 5 & 30 & 4.3 \\
\hline 27 & 5 & 4 & 4 & 5 & 4 & 4 & 4 & 30 & 4.3 \\
\hline 28 & 4 & 4 & 3 & 4 & 5 & 3 & 3 & 26 & 3.7 \\
\hline 29 & 5 & 4 & 3 & 5 & 4 & 3 & 3 & 27 & 3.9 \\
\hline 30 & 4 & 3 & 3 & 5 & 4 & 3 & 4 & 26 & 3.7 \\
\hline 31 & 5 & 5 & 5 & 4 & 3 & 3 & 3 & 28 & 4.0 \\
\hline
\end{tabular}




\begin{tabular}{|c|c|c|c|c|c|c|c|c|c|}
\hline 32 & 4 & 4 & 4 & 5 & 3 & 4 & 4 & 28 & 4.0 \\
\hline 33 & 5 & 4 & 3 & 4 & 3 & 5 & 5 & 29 & 4.1 \\
\hline 34 & 4 & 3 & 3 & 4 & 4 & 4 & 4 & 26 & 3.7 \\
\hline 35 & 5 & 5 & 5 & 4 & 3 & 5 & 5 & 32 & 4.6 \\
\hline 36 & 5 & 4 & 4 & 4 & 3 & 5 & 5 & 30 & 4.3 \\
\hline 37 & 4 & 4 & 3 & 4 & 4 & 3 & 4 & 26 & 3.7 \\
\hline 38 & 4 & 4 & 4 & 3 & 3 & 3 & 5 & 26 & 3.7 \\
\hline 39 & 4 & 4 & 3 & 4 & 4 & 3 & 3 & 25 & 3.6 \\
\hline 40 & 4 & 3 & 4 & 5 & 4 & 4 & 4 & 28 & 4.0 \\
\hline 41 & 5 & 4 & 5 & 5 & 4 & 4 & 4 & 31 & 4.4 \\
\hline 42 & 4 & 4 & 4 & 4 & 5 & 5 & 4 & 30 & 4.3 \\
\hline 43 & 4 & 4 & 5 & 5 & 3 & 4 & 4 & 29 & 4.1 \\
\hline 44 & 5 & 4 & 5 & 3 & 4 & 4 & 4 & 29 & 4.1 \\
\hline 45 & 5 & 5 & 4 & 5 & 3 & 5 & 4 & 31 & 4.4 \\
\hline 46 & 4 & 4 & 5 & 5 & 5 & 4 & 4 & 31 & 4.4 \\
\hline 47 & 5 & 5 & 4 & 5 & 4 & 3 & 4 & 30 & 4.3 \\
\hline 48 & 5 & 4 & 4 & 4 & 3 & 4 & 3 & 27 & 3.9 \\
\hline 49 & 4 & 4 & 5 & 5 & 4 & 4 & 3 & 29 & 4.1 \\
\hline 50 & 4 & 5 & 3 & 4 & 5 & 3 & 3 & 27 & 3.9 \\
\hline$\Sigma$ & 218 & 192 & 180 & $\mathbf{2 1 9}$ & $\mathbf{1 8 4}$ & $\mathbf{1 7 7}$ & $\mathbf{1 8 0}$ & 1350 & 3.9 \\
\hline Maturity level & 4.36 & 3.84 & $\mathbf{3 . 6}$ & $\mathbf{4 . 3 8}$ & $\mathbf{3 . 6 8}$ & $\mathbf{3 . 5 4}$ & $\mathbf{3 . 6}$ & $\mathbf{2 7}$ & 3.9 \\
\hline
\end{tabular}

Sumber: Data diolah, 2019

Untuk mengetahui tingkat kematangan penggunaan teknologi di Pemerintah Kabupaten Blitar penulis menggunakan domain PO (Perencanaan dan Organisasi) berikut hasilnya:

1. P01: Menetapkan rencana strategis teknologi informasi bernilai 4,36.

2. P02: Menetapkan arsitektur informasi bernilai 3,84.

3. P06: Mengkomunikasikan tujuan dan arahan manajemen bernilai 3,6.

4. P08: Memastikan kesesuaian dengan kebutuhan eksternal bernilai 4,38.

5. P09: Menilai resiko bernilai 3,68.

6. P010: Mengatur proyek bernilai 3,54.

7. P011: Mengatur kualitas bernilai 3,6.

Dari tabel diatas dapat dlihat bahwa nilai masing-masing pertanyaan pada maturity level berada pada level 3,54 - 4,36 maksudnya adalah tingkat kematangan penggunaan teknologi informasi aplikasi SIMDA Keuangan berada pada level managed and measurable organisasi dapat mengukur dan memonitor prosedur yang ada sehingga mudah ditanggulangi jika terjadi penyimpangan. Proses yang ada sudah berjalan dengan baik dan konstan.

Domain DS (Penghantar dan Dukungan) juga digunakan untuk mengetahui efektivitas penggunaan teknologi informasi di Pemerintah Kabupaten Blitar,berikut hasilnya:

Tabel 2 Hasil Rekapitulasi Domain DS

\begin{tabular}{|c|c|c|c|c|c|c|c|}
\hline \multirow{2}{*}{ Responden } & \multicolumn{5}{|c|}{ Pertanyaan } & \multicolumn{2}{c|}{ Maturity Level } \\
\cline { 2 - 8 } & $\mathbf{1}$ & $\mathbf{2}$ & $\mathbf{3}$ & $\mathbf{4}$ & $\mathbf{5}$ & $\boldsymbol{\Sigma}$ & Mean \\
\hline 1 & 4 & 4 & 4 & 4 & 5 & 21 & 4.2 \\
\hline
\end{tabular}




\begin{tabular}{|c|c|c|c|c|c|c|c|}
\hline 2 & 4 & 5 & 5 & 3 & 4 & 21 & 4.2 \\
\hline 3 & 5 & 5 & 5 & 4 & 5 & 24 & 4.8 \\
\hline 4 & 4 & 4 & 4 & 3 & 3 & 18 & 3.6 \\
\hline 5 & 4 & 5 & 4 & 3 & 5 & 21 & 4.2 \\
\hline 6 & 4 & 3 & 4 & 4 & 4 & 19 & 3.8 \\
\hline 7 & 5 & 5 & 4 & 5 & 5 & 24 & 4.8 \\
\hline 8 & 4 & 4 & 5 & 3 & 3 & 19 & 3.8 \\
\hline 9 & 4 & 4 & 5 & 5 & 5 & 23 & 4.6 \\
\hline 10 & 5 & 4 & 5 & 4 & 5 & 23 & 4.6 \\
\hline 11 & 4 & 5 & 4 & 4 & 3 & 20 & 4 \\
\hline 12 & 5 & 5 & 4 & 4 & 3 & 21 & 4.2 \\
\hline 13 & 5 & 4 & 4 & 4 & 4 & 21 & 4.2 \\
\hline 14 & 3 & 3 & 3 & 2 & 4 & 15 & 3 \\
\hline 15 & 4 & 3 & 5 & 4 & 4 & 20 & 4 \\
\hline 16 & 3 & 4 & 4 & 3 & 3 & 17 & 3.4 \\
\hline 17 & 3 & 4 & 3 & 3 & 4 & 17 & 3.4 \\
\hline 18 & 5 & 5 & 4 & 5 & 5 & 24 & 4.8 \\
\hline 19 & 4 & 5 & 5 & 4 & 4 & 22 & 4.4 \\
\hline 20 & 5 & 4 & 4 & 4 & 4 & 21 & 4.2 \\
\hline 21 & 3 & 3 & 2 & 1 & 3 & 12 & 2.4 \\
\hline 22 & 2 & 4 & 4 & 2 & 4 & 16 & 3.2 \\
\hline 23 & 5 & 4 & 4 & 4 & 5 & 22 & 4.4 \\
\hline 24 & 4 & 4 & 5 & 4 & 4 & 21 & 4.2 \\
\hline 25 & 2 & 1 & 1 & 1 & 3 & 8 & 1.6 \\
\hline 26 & 4 & 4 & 5 & 3 & 4 & 20 & 4 \\
\hline 27 & 5 & 4 & 5 & 3 & 3 & 20 & 4 \\
\hline 28 & 5 & 3 & 5 & 5 & 4 & 22 & 4.4 \\
\hline 29 & 5 & 5 & 4 & 4 & 5 & 23 & 4.6 \\
\hline 30 & 5 & 5 & 4 & 5 & 5 & 24 & 4.8 \\
\hline 31 & 4 & 5 & 3 & 5 & 4 & 21 & 4.2 \\
\hline 32 & 2 & 5 & 4 & 3 & 4 & 18 & 3.6 \\
\hline 33 & 3 & 4 & 3 & 4 & 4 & 18 & 3.6 \\
\hline 34 & 4 & 3 & 5 & 4 & 5 & 21 & 4.2 \\
\hline 35 & 5 & 4 & 3 & 5 & 5 & 22 & 4.4 \\
\hline 36 & 3 & 4 & 4 & 4 & 4 & 19 & 3.8 \\
\hline 37 & 4 & 5 & 4 & 4 & 5 & 22 & 4.4 \\
\hline 38 & 2 & 3 & 2 & 4 & 4 & 15 & 3 \\
\hline 39 & 3 & 4 & 4 & 4 & 3 & 18 & 3.6 \\
\hline 40 & 4 & 5 & 4 & 5 & 5 & 23 & 4.6 \\
\hline 41 & 3 & 5 & 4 & 4 & 5 & 21 & 4.2 \\
\hline 42 & 3 & 5 & 5 & 3 & 5 & 21 & 4.2 \\
\hline 43 & 4 & 4 & 4 & 5 & 5 & 22 & 4.4 \\
\hline 44 & 4 & 3 & 3 & 3 & 5 & 18 & 3.6 \\
\hline 45 & 4 & 4 & 4 & 4 & 5 & 21 & 4.2 \\
\hline 46 & 4 & 4 & 5 & 5 & 4 & 22 & 4.4 \\
\hline
\end{tabular}




\begin{tabular}{|c|c|c|c|c|c|c|c|}
\hline 47 & 3 & 3 & 3 & 3 & 5 & 17 & 3.4 \\
\hline 48 & 4 & 3 & 3 & 4 & 5 & 19 & 3.8 \\
\hline 49 & 2 & 4 & 3 & 3 & 5 & 17 & 3.4 \\
\hline 50 & 3 & 3 & 2 & 3 & 5 & 16 & 3.2 \\
\hline$\Sigma$ & 192 & 202 & 196 & 186 & 214 & $\mathbf{9 9 0}$ & 4 \\
\hline Maturity level & 3.84 & 4.04 & 3.92 & 3.72 & $\mathbf{4 . 2 8}$ & $\mathbf{1 9 . 8}$ & 4 \\
\end{tabular}

Sumber: Data diolah, 2019

Untuk mengetahui tingkat kematangan implentasi penggunaan teknologi penulis menggunakan domain DS (Penghantar dan Dukungan) berikut hasilnya:

1. DS1: Menetapkan dan mengatur tingkatan pelayanan bernilai 3,84.

2. DS3: Mengelola kapasitas dan kinerja bernilai 4,04.

3. DS4: Menjamin layanan berkelanjutan bernilai 3,92

4. DS10: Mengelola kegiatan dan permasalahan bernilai 3,72.

5. DS12: Mengelola fasilitas bernilai 4,28.

Dari tabel diatas dapat dlihat bahwa nilai masing-masing pertanyaan pada maturity level berada pada level 3,72 - 4,28 maksudnya adalah tingkat kematangan penggunaan teknologi informasi aplikasi SIMDA Keuangan berada pada level managed and measurable organisasi dapat mengukur dan mengawasi prosedur yang ada sehingga mudah dicegah jika terjadi penyimpangan. Implementasi SIMDA Keuangan berjalan dengan baik dan konstan.

Untuk mencapai tujuan penggunaan teknologi informasi dari pengguna aplikasi itu sendiri, organisasi dan masyarakat dapat memanfaatkan sumber daya manusia dan teknologi informasi sehingga tujuan tercapai. Untuk mencapai tujuan tersebut, adapun solusi dari permasalah ini yaitu:

1. Pergantian jabatan pada Pemerintah Kabupaten Blitar karena kenaikan jabatan atau faktor lain sudah seharusnya pegawai yang menempati jabatan baru tersebut harus mengikuti pelatihan yang dilaksanakan oleh pembuat dan pengembang aplikasi SIMDA Keuangan yaitu BPKP agar penggguna dapat memahami menumenu yang terdapat di aplikasi SIMDA Keuangan meliputi penganggaran, penatausahaan, akuntansi dan pelaporan, serta pengembangan diri dari pengguna dapat tercapai.

2. Pegawai yang menempati jabatan baru harusnya menciptakan komunikasi yang baik antar sesama rekan kerja, seperti bertanya mengenai detail penggunaan aplikasi SIMDA Keuangan mulai dari input, proses, hingga menjadi output laporan keuangan.

3. Untuk menyesuaikan kebijakan baru dari Pemerintah mengenai Penerapan Standar Akuntansi Berbasis Accrual, harusnya pegawai melakukan pembelajaran melalui pedoman yang diberikan Pemerintah dan bertukar pendapat dengan sesama rekan kerja demi kebaikan pembuatan sesuai prosedur.

4. Pegawai harus mempunyai semangat belajar secara terus menerus dan memahami menu-menu aplikasi SIMDA Keuangan dan alur pembuatan laporan keuangan demi tercapainya informasi yang akurat dan menghasilkan opini Wajar Tanpa Pengecualian.

5. Aplikasi SIMDA Keuangan juga harus benar-benar dimantapkan dan diuji apakah menu-menu yang digunakan untuk menginput selaras dengan aturan pemerintah dan prinsip-prinsip menyusun laporan keuangan. Sehingga aplikasi SIMDA 
Keuangan tidak berubah-ubah dan tidak membingungkan penggunanya dan efektif dalam mencapai tujuan.

\section{KESIMPULAN}

Pengukuran efektivitas penggunaan teknologi informasi di Pemerintah Kabupaten Blitar dengan COBIT domain PO (Perencanaan dan Organisasi) dan domain DS (Penghantar dan Dukungan) telah mencapai level 4 managed and measurable artinya tanggungjawab pengelola TI pada implementasi SIMDA Keuangan telah disosialisasikan kepada seluruh pegawai serta dijalankan ditaati sesuai prosedur. Pemerintah juga dapat mengevaluasi dan mencegah resiko yang akan terjadi dengan kata lain menghindari penyimpangan. Standar yang ditetapkan mengenai implementasi SIMDA Keuangan sudah dilaksanakan secara efektif sesuai prosedur dan terintegrasi secara online dengan seluruh SKPD. Implementasi SIMDA Keuangan dalam memanfaatkan teknologi informasi sudah secara konstan. Untuk memenuhi kebutuhan dalam mengelola keuangan otomasi dan perangkat teknologi telah dilengkapi. Sehingga kualitas laporan keuangan pertanggungjawaban daerah dapat lebih baik dan menghasilkan Opini Wajar Tanpa Pengecualian.

\section{DAFTAR PUSTAKA}

Azizah, Noor. 2017. Audit Sistem Informasi Menggunakan Framework Cobit 4.1 Pada ELearning Unisnu Jepara. Jurnal SIMETRIS. Vol 8: 377-382. Universitas Islam Nahdlatul Ulama Jepara. Jepara.

Badan Pemeriksa Keuangan Dan Pembangunan. 2008. SIMDA dan Penerapannya. BPKP Pusat. Jakarta.

Darmawan, Deni dan Kunkun Nur Fauzi. 2013. Sistem Informasi Manajemen. Remaja Rosdakarya. Bandung.

Hermanto, Dedy dan Desy Iba Ricoida. 2014. Analisis Pengukuran Tingkat Kematangan Menggunakan Kerangka COBIT 4.1 (Studi Kasus PT.SMI). 22-32 Jurnal SESINDO. STMIK GI MDP. Palembang.

O’brien, James A dan George M. Marakas. 2014. Management Information Systems. Nine edition. Mc Graw Hill. NYC. Terjemahan Puspitasari, Liza Nurbani dan Hirson Kurnia. 2014. Sistem Informasi Manajemen. Edisi Sembilan. Jilid 1. Salemba Empat. Jakarta.

Putra, Iwan Setya. 2011. Evaluasi Penerapan Sistem Informasi Akuntansi Pada Sistem Dan Prosedur Belanja Di Pemerintah Kota Blitar. Jurnal Kompilasi IImu Ekonomi (KOMPILEK). 3(1): 68-91. LPPM STIEKEN Blitar. Blitar.

Sudiro, Achmad, Perdana Rahadian, dan Nur Prima. 2017. Sistem Informasi Manajemen. Universitas Brawijaya Press. Malang

Surbakti, Herison. 2012. Managing Control Object For It (COBIT) Sebagai Standar Framework Pada Proses Pengelolaan It-Governance Dan Audit Sistem Informasi. Jurnal Teknologi Informasi. Vol VII: 1-14. Universitas Respati. Yogyakarta.

Sutabri, Tata. 2014. Sistem Informasi Manajemen (Edisi Revisi). Andi. Yogyakarta. 